\title{
The Impact of Social Media Marketing on Customer Inspiration and Customer Purchase Intention: A Case Study on Kabul-Afghanistan Telecom Industry
}

\author{
Hamayoun GHAFOURZAY iD a Nurettin PARILTI iD b \\ a Ankara Hacı Bayram Veli University, Institute of Graduate Programs, Business Administration Department, Ankara, Turkey. \\ hamayoun.ghafourzay@yahoo.com \\ b Ankara Hacı Bayram Veli University, Faculty of Economics and Administrative Science, Ankara, Turkey. nurettinparilti@gmail.com
}

\begin{tabular}{|c|c|}
\hline ARTICLE INFO & ABSTRACT \\
\hline $\begin{array}{l}\text { Keywords: } \\
\text { Social Media }\end{array}$ & $\begin{array}{l}\text { Purpose - This study investigates the impact of social media marketing on customer inspiration and } \\
\text { customer purchase intention in the telecommunication sector of Afghanistan. }\end{array}$ \\
\hline $\begin{array}{l}\text { Customer Inspiration } \\
\text { Customer Purchase Intention } \\
\text { Telecom Industry } \\
\text { Afghanistan }\end{array}$ & $\begin{array}{l}\text { Design/methodology/approach - For examining the mentioned purpose, empirical research was } \\
\text { conducted on the telecommunication sector of Afghanistan. Social media users formed the study } \\
\text { population, following the telecommunications companies' social media accounts in the capital } \\
\text { Kabul. A self-managed online survey was administered using the convenience sampling method. A } \\
\text { total of } 4 \text { oo valid responses were taken for analysis as the sample of the study. The collected data } \\
\text { was analyzed using the IBM SPSS Statistics } 25 \text { to test the suggested hypotheses. Frequency analysis, } \\
\text { correlation analysis, and linear regression analysis were used to analyze the obtained data. }\end{array}$ \\
\hline $\begin{array}{l}\text { Received } 24 \text { May } 2020 \\
\text { Revised } 29 \text { August } 2020 \\
\text { Accepted } 15 \text { September } 2020\end{array}$ & $\begin{array}{l}\text { Findings - The results revealed that social media marketing, customer inspiration, and customer } \\
\text { purchase intention were significantly and positively correlated. Besides, all the suggested } \\
\text { hypotheses were accepted, indicating that social media marketing has a significant positive impact } \\
\text { on customer inspiration and customer purchase intention. }\end{array}$ \\
\hline $\begin{array}{l}\text { Article Classification: } \\
\text { Research Article }\end{array}$ & $\begin{array}{l}\text { Originality - Although some studies examine consumer inspiration in different contexts, extant } \\
\text { literature does not provide an empirical study on examining the impact of social media marketing } \\
\text { on customer inspiration and purchase intention. This research, therefore, addresses a gap in } \\
\text { customer inspiration and offers valuable perspectives for the literature. This research also provides } \\
\text { a sound basis of implications for telecom companies and their stakeholders. }\end{array}$ \\
\hline
\end{tabular}

\section{Introduction}

In recent years, social media development has changed the advertising and marketing landscape and has turned into a tool that businesses and corporations would do well to exploit. Buffer (2019), states that 73\% of online marketers believe that their strategies have effectively executed their company's social media marketing strategy. Therefore, investigating the impact of social media marketing (SMM) on customer inspiration (CI) and customer purchase intention (PI) is vitally important for businesses, digital marketers, marketing managers, and marketing researchers. Most existing studies concentrate on exploring the impact of social media marketing on purchase intention in different contexts (Ceyhan, 2019; Karayalçin, 2019; Laksamana, 2018; Çinkay, 2017; Balakrishnan, Dahnil, \& Yi, 2014; Kim \& Ko, 2012). Love marks Campus (2011) illustrates that inspired consumers are brand owners, brand advocates, and deeply immersed community members. Moreover, Pfrang, Rudolph, \& Böttger (2014) indicate that customer inspiration can significantly influence customer loyalty and purchase amount. Recently, Böttger, Rudolph, Evanschitzky, \& Pfrang (2017) conceptualized and developed a 10-item scale of customer inspiration. Also, Böttger et al., (2017) illustrated customer inspiration relationship with customer satisfaction, customer loyalty, and the likelihood of purchase. Khan \& Ghouri (2018) theorized the mediating role of customer inspiration in examining the impact of customer-defined market orientation on customer satisfaction and customer loyalty. Moreover, Ghouri, Kin, Yunus, \& Akhtar (2019) intended to validate customer inspiration in Malaysia. Ghouri et al. (2019) further point out that customer inspiration mediates the market orientation and customer loyalty subcontracts.

Nathues (2017) recommends that the research on customer inspiration in a marketing context is scarce, and the media used to transmit the stimuli needs to be researched, such as social media. While these studies

\section{Suggested Citation}

Ghafourzay, H., Parıltı, N. (2020). The Impact of Social Media Marketing on Customer Inspiration and Customer Purchase Intention: A Case Study on Kabul-Afghanistan Telecom Industry, Journal of Business Research-Turk, 12 (3), 2721-2732. 
illustrate the customer inspiration in various ways, there is still no empirical research investigating the impact of social media marketing on customer inspiration and purchase intention. Thus, based on the Nathues's (2017) recommendation, this study aims to fill this research gap by empirically examining the impact of social media marketing on customer inspiration and customer purchase intention in the telecommunication industry of Afghanistan.

\section{Theoretical Framework}

\subsection{Social Media Marketing}

Often referred to as "online marketing," "internet marketing," or "web marketing," digital marketing has become more popular over the last decade. Social media marketing as a new discipline of digital marketing is an interdisciplinary and cross-functional phenomenon that often utilizes social media in combination with other channels of communication to pursue organizational objectives through value creation for stakeholders (Felix, Rauschnabel, \& Hinsch, 2017).

Worldwide, the total number of social media users is expected to rise to 3.29 billion in 2022, representing $42.3 \%$ of the world's population(eMarketer, 2018). This potential user consumes several hours on different platforms of social media. The marketers thus endorse the ever-changing social media as an effective marketing channel (Appel, Grewal, Hadi, \& Stephen, 2019).

Hundreds of websites will count as social media outlets. Social media services can be categorized, but they have slightly overlapping boundaries (Dummies, 2017). Knowing the most popular social media sites around is useful. It will enable businesses to leverage their brand's impact on social media, connect with the right people, and achieve their goals on social media (Lua, 2019). According to Statista, 2020's most popular social media sites are stated below:

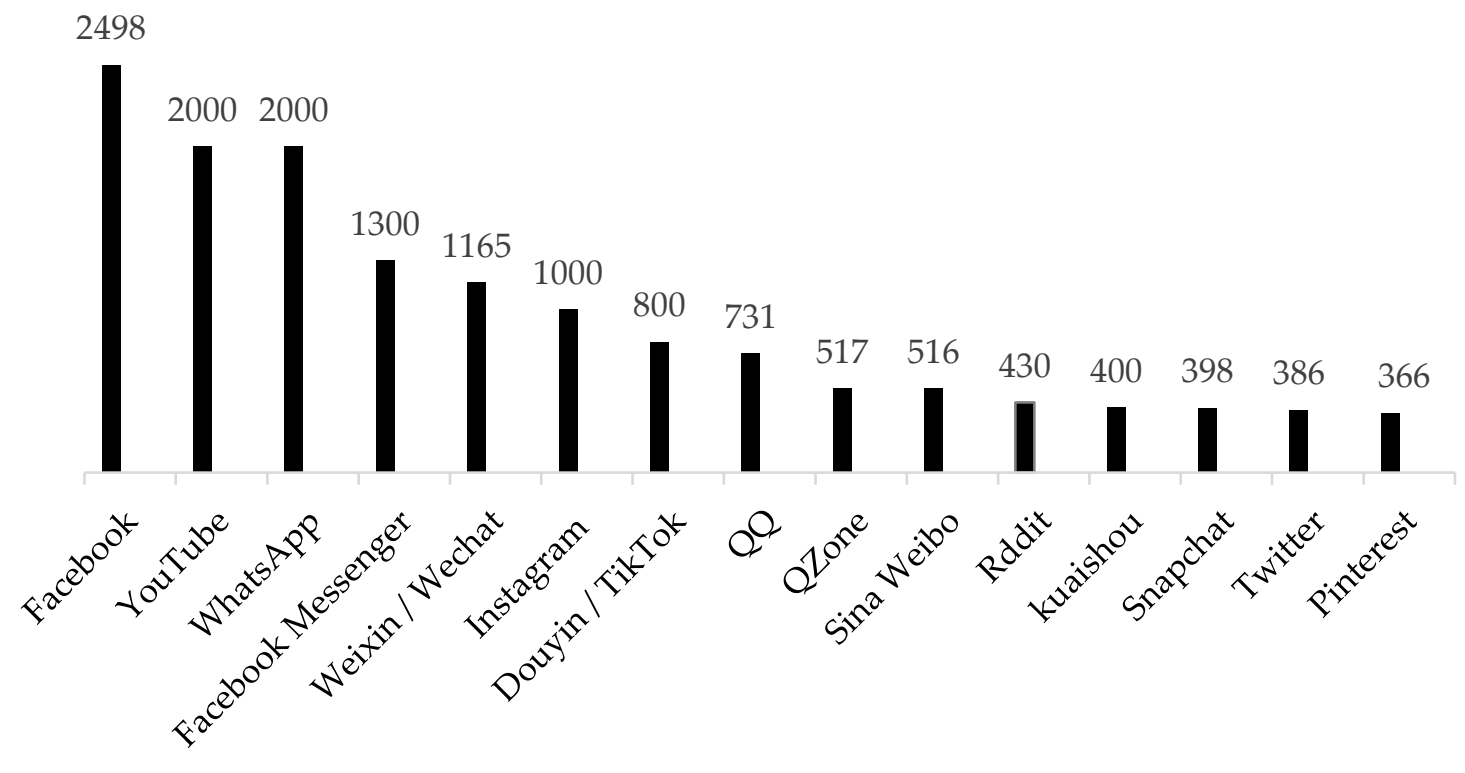

Figure 1: Global social networks ranked by number of users in millions (www.statista.com)

Social media marketing activities were categorized as entertainment, interaction, trendiness, customization, and word of mouth by Kim \& Ko (2012). Additionally, the Kim \& Ko (2012) explain that social media marketing efforts will indirectly increase purchase intention. Ural \& Yuksel (2015) and Gautam \& Sharma (2017) show that social media marketing efforts have a positive impact on purchase intention.

\subsection{Customer Inspiration}

Social psychology defines inspiration as a dualistic concept that includes a cognitive and motivational component. (Thrash \& Elliot, 2004). Per this definition, inspiration involves "the realization of a new insight or idea" and "creates a motivation to act upon this inspiration"(Böttger, 2015). Additionally, Böttger (2015) has proposed two ways of inspiring consumers. First, consumers can be inspired by a new means of achieving an 
existing goal. For instance, an innovative product that provides a new and better means of achieving existing goals. Secondly, consumers can be inspired by a new goal. In addition, Böttger (2015) has developed a 6phased iterative process, called the customer inspiration cycle, as a marketing inspiration framework. (Figure 2).

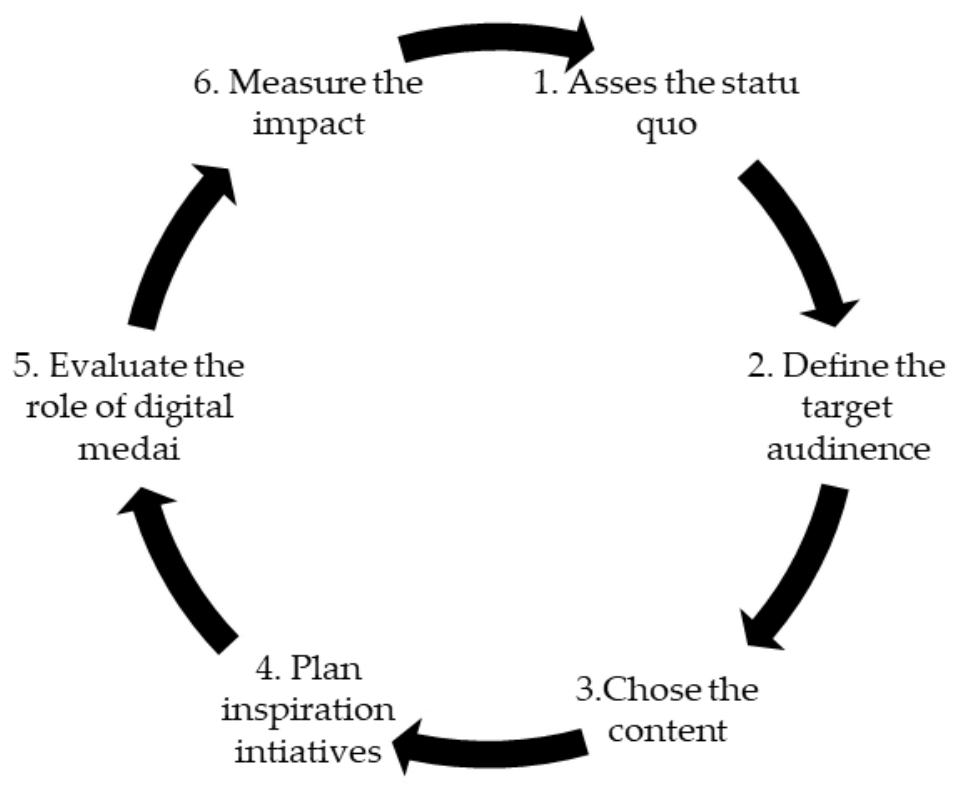

Figure 2: Customer inspiration circle (Böttger, 2015)

Nathues (2017) study points out inspiration as an effective new marketing discipline made possible by new digital networks that fill a gap in emotional marketing and consumer behavior studies to overcome the challenges marketing professionals face. Additionally, the researcher suggests that it is important to investigate the media used to convey the stimuli besides inspirational stimuli. Like social media, or is it the combination of digital and traditional techniques, whichever inspires customers the most.

\subsection{Customer Purchase Intention}

Lu et al. (2014) define the purchase intentions as "Consumers' willingness to buy a given product at a specific time in a specific situation." Laksamana's (2018) findings confirm that social media marketing positively affects purchase intention in the Indonesian banking industry. Moreover, Böttger (2015) illustrates that in line with the motivational portion of inspiration, customer inspiration increases spending by enhancing the desire to purchase a good or service. Furthermore, Böttger's findings demonstrated a negative correlation between impulse buying and all other consequences, stating competitive mediation via impulse buying.

\section{Methodology}

This study has employed empirical research with a cross-sectional approach. The population of the study consisted of different social media users who follow the social media accounts of Afghanistan's telecommunications companies in the capital Kabul. A self-managed online survey using the convenience sampling method was administered using Google Drive to gather data from the target population. The data was collected "between" May 06, 2019, and October 23, 2019. The respondents are subscribers of telecommunications companies in Kabul, Afghanistan. A total of 400 usable and non-defective responses stored in Google Drive were considered the study's sample size. According to Gürbüz \& Şahin, the minimum sample size for the target population of 10 million with a confidence level of 95 percent at least should be 384 (Gürbüz \& Şahin, 2018:130).

The hypotheses of the study are as follows: 
H1: Social media marketing has a positive impact on customer inspiration.

$\mathrm{H}_{2}$ : Social media marketing has a positive impact on customer purchase intention.

$H_{3}:$ Customer inspiration has a positive impact on customer purchase intention.

Figure 3, displays a diagram of the research model. As shown below:

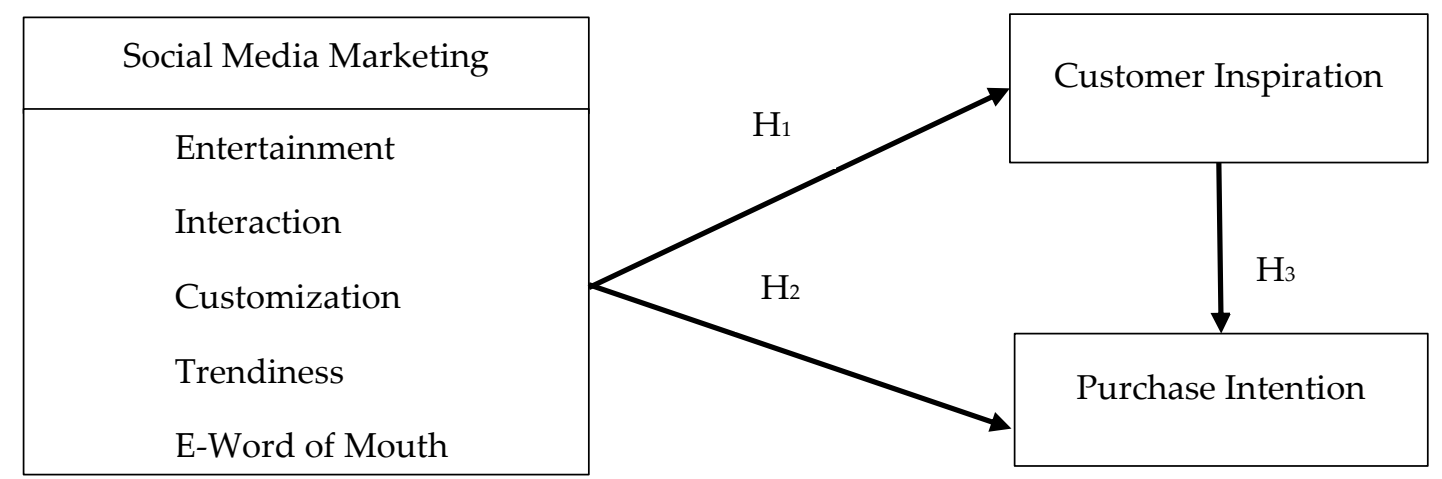

Figure 3. Research model

The administered questionnaire consists of three sections. The first part deals with some demographic questions. In contrast, the second part includes questions about social media marketing and customer purchasing intention, and the last part of the questionnaire deals with questions regarding customer inspiration. The scale of social media marketing measures the telecommunications industry's social media marketing activities in five dimensions: 1 . Entertainment, 2. Interactions, 3. Trendiness, 4. Customization, and, 5. Electronic word of mouth. In this context, the 11-item scale of Kim \& Ko (2012) was adopted to measure telecommunications companies' social media marketing activities. While the 4-item purchasing intention scale was taken from Bolton and Drew (1991) and customer inspiration was assessed by the 10-item scale of Böttger (2015). All the mentioned survey questions were assessed using five-point Likert-type scales (5=strongly agreed, 1 =strongly disagreed).

For the determination of the reliability of the collected data, the internal consistency of each measurement scale was calculated using Cronbach's alpha coefficients. The value of each scale was greater than 0.80 , as shown in Table 1. According to Sekaran \& Bougie (2003), the value in the range of 0.80-0.90 is considered as good. Therefore, the adopted scales were considered to be reliable.

Table 1. Reliability Statistics

\begin{tabular}{lccl}
\hline Scale & Cronbach's Alpha & N of Items & Remarks \\
\hline Social Media Marketing & .858 & 11 & Accepted \\
Customer Inspiration & .868 & 10 & Accepted \\
Customer Purchase Intention & .871 & 4 & Accepted \\
\hline
\end{tabular}

In order to check the validity of the collected data; as a requirement before carrying out the factor analysis, the Kaiser-Meyer-Olkin (KMO) and the Bartlett Sphericity Sampling Adequacy Test were used. The results are presented in Table 2. It shows that KMO values are $0.887,0.898$, and 0.82 , respectively; (above 0.60 ) means that the sample is adequate for factor analysis. Bartlett's Sphericity tests were significant as their values were equal to 0.000; (less than 0.05) shows the data convenience level for factor analysis. Therefore, data considered appropriate for Confirmatory Factor Analysis (CFA). 
Table 2. KMO and Bartlett's Test

\begin{tabular}{lcccc}
\hline & & $\begin{array}{c}\text { Social Media } \\
\text { Marketing }\end{array}$ & $\begin{array}{c}\text { Customer } \\
\text { Inspiration }\end{array}$ & $\begin{array}{c}\text { Purchase } \\
\text { Intention }\end{array}$ \\
\hline \multicolumn{2}{c}{ Kaiser-Meyer-Olkin Measure of Sampling Adequacy. } & .887 & .898 & .822 \\
\hline \multirow{2}{*}{$\begin{array}{l}\text { Bartlett's Test } \\
\text { of Sphericity }\end{array}$} & Approx. Chi-Square & 1379.543 & 1826.518 & 761.610 \\
& Df & 55 & 45 & 6 \\
\hline
\end{tabular}

After the previous steps, as an extraction method, the Principal Component Analysis (PCA) was employed. The result of PCA revealed that the factor loadings range between 0.601-0.922, (greater than 0.60), and the Total Variance Extracted (TVE) for adopted scales (SMM, CI, and PI) were $60.00 \%, 62.13 \%$, and $71.70 \%$ respectively; (greater than $50 \%$ ), which is considered acceptable.

For testing the suggested hypotheses, the gathered data was analyzed through the IBM SPSS Statistics 25 . The frequency analysis, correlation analysis, and linear regression analysis were used to analyze the collected data.

\section{Findings}

Firstly, the demographics of the respondents were depicted using frequency analysis. As shown throughout Table 3, respondents' demographic and social subsets are gender, age, marital status, educational level, employment status, and some figures on Internet usage, social media application usage, and the daily usage of social media.

Characteristics of respondents based on the results of descriptive analysis showed that males were the majority with $323(80.8 \%)$, while female respondents were 77 (19.3\%). Based on age data (20-29), the age group has constituted the most significant part of respondents with $150(63.2 \%)$, while only $4(1.0 \%)$ respondents were (50 or over) years old with the minimum percentage. Most of the respondents, $230(57.5 \%)$ were single, while $167(41.8 \%)$ were married. The majority of data providers have an undergraduate background, 211 respondents who make up (52.8\%) of the data set; master \& Ph.D. are (35.8\%), while $(2.3 \%)$ are with primary education. The majority of data providers, 147 respondents $(36.8 \%)$ are from the public sector, while 120 $(23.5 \%)$ come from the educational sector (students).

Table 3. Demographic Profile of the Sample $(n=400)$

\begin{tabular}{cccc}
\hline Demographics & Variables & Frequency & Percentage \\
\hline \multirow{2}{*}{ Gender } & Male & 323 & 80.8 \\
& Female & 77 & 19.3 \\
\hline \multirow{3}{*}{ Age } & Below 20 & 43 & 10.8 \\
& $20-29$ & 253 & 63.2 \\
& $30-39$ & 96 & 24.0 \\
& $40-49$ & 4 & 1.0 \\
& 50 and above & 4 & 1.0 \\
\hline \multirow{3}{*}{ Marital Status } & Single & 230 & 57.5 \\
& Married & 167 & 41.8 \\
& Divorced & 1 & 0.3 \\
& Another & 2 & 0.5 \\
\hline \multirow{2}{*}{ Education Level } & Primary & 9 & 2.3 \\
& Secondary Education & 37 & 9.3 \\
& Undergraduates & 211 & 52.8 \\
& Master and PhD & 143 & 35.8 \\
\hline \multirow{2}{*}{ Occupation } & Public Sector & 147 & 36.8 \\
& Private Sector & 86 & 21.5 \\
& Self-employed & 42 & 10.5 \\
& Student & 120 & 30.0 \\
& Retired & 5 & 1.3 \\
\hline
\end{tabular}




\begin{tabular}{|c|c|c|c|}
\hline \multirow{5}{*}{ Internet Usage } & Less than 1 year & 16 & 4.0 \\
\hline & 1-5 Years & 111 & 27.8 \\
\hline & 6-10 Years & 192 & 48.0 \\
\hline & 11-15 Years & 61 & 15.3 \\
\hline & 16 years and above & 20 & 5.0 \\
\hline \multirow{9}{*}{ Social Media Applications } & Facebook & 390 & 97.5 \\
\hline & Instagram & 237 & 59.3 \\
\hline & Twitter & 145 & 36.3 \\
\hline & You Tube & 268 & 67.0 \\
\hline & LinkedIn & 15 & 03.8 \\
\hline & WhatsApp & 26 & 06.5 \\
\hline & Telegram & 8 & 02.0 \\
\hline & Snapchat & 4 & 01.0 \\
\hline & Other & 20 & 05.0 \\
\hline \multirow{5}{*}{$\begin{array}{c}\text { Daily Usage of Social Media } \\
\text { Applications }\end{array}$} & Less than 1 hour & 72 & 18.0 \\
\hline & 1-3 hours & 228 & 57.0 \\
\hline & 4-6 hours & 58 & 14.5 \\
\hline & More than 6 hours & 37 & 9.3 \\
\hline & Never & 5 & 1.3 \\
\hline \multirow{6}{*}{$\begin{array}{l}\text { Telecommunication } \\
\text { Companies }\end{array}$} & Afghan Telecom & 38 & 09.5 \\
\hline & Roshan & 118 & 29.6 \\
\hline & AWCC & 80 & 20.1 \\
\hline & MTN & 142 & 35.6 \\
\hline & Salaam & 28 & 07.0 \\
\hline & Etisalat & 247 & 61.9 \\
\hline
\end{tabular}

As shown in Table 3, almost $48.0 \%$ of the respondents used the internet for $6-10$ years, while $4.0 \%$ use the internet for less than one year. Most of the respondents 390 (97.5\%) use Facebook, while $67.0 \%, 59.3 \%, 36.3 \%$, and $06.5 \%$ use YouTube, Instagram, Twitter, and WhatsApp respectively. Considering the daily usage of social media applications of the respondents, majority of them $228(57 \%)$ use social media for 1-3 hours, while 72 $(18 \%), 58(14.5 \%)$, and $37(9.3 \%)$ of the respondents use social media for (less than 1) hour, (4-6) hours and (more than 6) hours respectively. Considering the telecom company used by the respondents, most of them $247(61.9 \%)$ use Etisalat, while $142(35.6 \%), 118(29.6 \%), 80(20.1 \%)$ are use MTN, Roshan, and AWCC respectively.

Secondly, a Pearson product-moment correlation, documented in given Table 4, was conducted to examine the relationships between social media marketing, customer inspiration, and purchase intention. Social media marketing was more strongly positively correlated to customer inspiration, $\mathrm{r}(398)=.717, \mathrm{p}<.001$, than to compare to purchase intention, $\mathrm{r}(398)=.636, \mathrm{p}<.001$. The customer inspiration was also medium positively related to purchase intention, $\mathrm{r}(398)=.629, \mathrm{p}<.001$. The results are shown in Table 4.

Table 4. General Mean, Standard Deviation, and Correlations $(n=400)$

\begin{tabular}{lcccc}
\hline \multicolumn{1}{c}{ Variables } & $\mathrm{M}$ & $\mathrm{SD}$ & $\mathrm{CI}$ & PI \\
\hline Social Media Marketing (SMM) & 3.0120 & 0.88 & $.717^{* *}$ & $.636^{* *}$ \\
Customer Inspiration (CI) & 3.2606 & 1.05 & - & $.629^{* *}$ \\
Purchase Intention (PI) & 3.1336 & 0.77 & - & - \\
\hline
\end{tabular}

Note. ${ }^{* *}$ Correlation is significant at the 0.01 level (2-tailed).

Thirdly, a Pearson product-moment correlation, was conducted to examine the relationships among social media marketing dimensions, customer inspiration, and customer purchase intention. As indicated in Table 
5, The Inter-Item detailed correlation matrix for social media marketing dimensions indicates a medium positive relationship among social media marketing dimensions, customer inspiration, and customer purchase intention.

Table 5. Inter-Item Correlation Matrix for Social Media Marketing Dimensions ( $n=400)$

\begin{tabular}{lccccccc}
\hline \multicolumn{1}{c}{ Variables } & 1 & 2 & 3 & 4 & 5 & CI & PI \\
\hline 1.Entertainment & - & & & & & \\
2.Interaction & $.417^{* *}$ & - & & & & \\
3.Trendiness & $.477^{* *}$ & $.554^{* *}$ & - & & & \\
4.Customization & $.400^{* *}$ & $.480^{* *}$ & $.530^{* *}$ & - & & \\
5.eWOM & $.423^{* *}$ & $.489^{* *}$ & $.490^{* *}$ & $.494^{* *}$ & - & \\
Customer Inspiration (CI) & $.509^{* *}$ & $.579^{* *}$ & $.530^{* *}$ & $.504^{* *}$ & $.589^{* *}$ & - & \\
Purchase Intention (PI) & $.417^{* *}$ & $.476^{* *}$ & $.448^{* *}$ & $.477^{* *}$ & $.574^{* *}$ & $.629^{* *}$ & - \\
\hline
\end{tabular}

Note. ${ }^{* *}$ Correlation is significant at the 0.01 level (2-tailed).

Fourthly, a bivariate regression was conducted to examine how social media marketing predicts customer inspiration. A scatterplot showed that the relationship between social media marketing and customer inspiration was positive and linear and did not reveal any bivariate outliers. An analysis of standard residual showed that the data contained no outliers (Std. residual Min $=-2.478$, Std. Residual Max $=2.584$ ). Independence of residual errors was confirmed with a Durbin-Watson test $(d=1.822)$. Residual plots showed the normality of the residuals.

Social media marketing statistically significantly predicted customer inspiration, $F(1,398)=421.824, \quad p<.001$, the $\mathrm{R}^{2}$ for this equation was 0.515 ; that is, $51.5 \%$ of the variance in customer inspiration was predictable from social media marketing. Henseler (2010) proposed a rule of thumb for acceptable $\mathrm{R}^{2}$ with $0.75,0.50$, and 0.25 described as substantial, moderate, and weak. Therefore, this is a moderate relationship. The correlation between social media marketing and customer inspiration was statistically significant, $\mathrm{r}(398)=.717, p<.001$. The regression equation for predicting customer inspiration from social media marketing was $\hat{y}=0.45+0.816 \mathrm{X}$ (Social Media Marketing). The confidence interval for the slope to predict customer inspiration from social media marketing was $95 \% \mathrm{CI}[.895, .738]$ with a $\mathrm{B}=.717$; thus, for each unit of increased social media marketing, customer inspiration increases by about 0.7 to 0.9 points.

Table 6. Linear Regression Analysis between Social Media Marketing and Customer Inspiration ( $n=400)$

\begin{tabular}{lccccc}
\hline Variables & $\mathrm{B}$ & $\mathrm{SE}$ & $\mathrm{t}$ & $\beta$ & $\mathrm{V}$ \\
\hline SMM & .816 & .040 & 20.538 & .717 & 1.000 \\
(Constant) & .454 & .128 & 3.537 & - & - \\
\hline
\end{tabular}

a. Predictors: SMM, (Constant).

b. Dependent Variable: $C I, R^{2}=0.515$, Adjusted $R^{2}=0.513, F(1,398)=421.824, p<.001$

As indicated in Table 7, the multiple regression for social media marketing dimensions indicates that social media marketing dimensions statistically significantly predicted customer inspiration, $\mathrm{F}(5,394)=85.214, \mathrm{p}$ $<.001$. The $\mathrm{R}^{2}$ for this equation is 0.520 ; that is, $52.0 \%$ of the customer inspiration variance was predictable from social media marketing dimensions. Therefore, according to Henseler (2010), this is a moderate relationship. 
H. Ghafourzay - N. Par1ltı 12/3 (2020) 2721-2732

Table 7. Multiple Regression Analysis between Social Media Marketing Dimensions and Customer Inspiration

\begin{tabular}{lcccccc}
\multicolumn{7}{c}{$(n=400)$} \\
\hline Variables & $\mathrm{B}$ & $\mathrm{SE}$ & $\mathrm{t}$ & $\mathrm{Sig}$. & $\beta$ & $\mathrm{VIF}$ \\
\hline Entertainment & .230 & .050 & 4.589 & .000 & .191 & 1.425 \\
Interaction & .220 & .039 & 5.587 & .000 & .252 & 1.667 \\
Trendiness & .060 & .028 & 2.157 & .032 & .102 & 1.826 \\
Customization & .061 & .023 & 2.600 & .010 & .116 & 1.621 \\
eWOM & .205 & .033 & 6.314 & .000 & .278 & 1.593 \\
(Constant) & .452 & .137 & 3.297 & .001 & - & - \\
\hline
\end{tabular}

a. Predictors: Entertainment, Interaction, Trendiness, Customization, eWOM, (Constant).

b. Dep. Variable: Customer Inspiration, $R^{2}=0.520$, Adjusted $R^{2}=0.513, F(5,394)=85.214, p<.001$.

Fifthly, a bivariate regression was conducted to examine how social media marketing predicts purchase intention. A scatterplot showed that the relationship between social media marketing and purchase intention was positive and linear and did not reveal any bivariate outliers. The correlation between social media marketing and purchase intention was statistically significant, $r(398)=0.636, p<0.001$. The regression equation for predicting purchase intention from social media marketing was $\hat{y}=0.55+0.864 X$ (Social Media Marketing). The $\mathrm{R}^{2}$ for this equation was 0.405 ; that is, $40.5 \%$ of the purchase intention variance was predictable from social media marketing. According to Henseler (2010), this is a moderate relationship. The bootstrapped 95\% confidence interval for the slope to predicate purchase intention from social media marketing ranges from 0.760 to 0.967 ; thus, for each one-unit of social media marketing increase, customer inspiration increased by 0.738 to 0.967 points.

Table 8. Linear Regression Analysis between Social Media Marketing and Customer Purchase Intention ( $n=400)$

\begin{tabular}{cccccc}
\hline Variables & $\mathrm{B}$ & $\mathrm{SE}$ & $\mathrm{t}$ & $\beta$ & $\mathrm{VIF}$ \\
\hline PI & .864 & .052 & 16.462 & .636 & 1.000 \\
(Constant) & .555 & .169 & 3.276 & - & - \\
\hline
\end{tabular}

a. Predictors: SMM, (Constant).

b. Dependent Variable: PI, $R^{2}=0.405$, Adjusted $R^{2}=0.404, F(1,398)=270.981, p<.001$.

As indicated in Table 9., the multiple regression for social media marketing dimensions indicates, social media marketing dimensions statistically significantly predicted purchase intention, $F(5,394)=56.907, p<.001$. The $\mathrm{R}^{2}$ for this equation is .419; that is, $41.9 \%$ of the variance in purchase intention was predictable from social media marketing dimensions. Therefore, according to Henseler (2010), this is a moderate relationship.

Table 9. Regression Analysis between Social Media Marketing Dimensions and Purchase Intention ( $n=400)$

\begin{tabular}{lcccccc}
\hline Variables & $\mathrm{B}$ & $\mathrm{SE}$ & $\mathrm{t}$ & $\mathrm{Sig}$. & $\beta$ & $\mathrm{VIF}$ \\
\hline Entertainment & .170 & .066 & 2.585 & .010 & .118 & 1.425 \\
Interaction & .158 & .052 & 3.063 & .002 & .152 & 1.667 \\
Trendiness & .039 & .037 & 1.065 & .288 & .055 & 1.826 \\
Customization & .098 & .031 & 3.205 & .001 & .157 & 1.621 \\
eWOM & .304 & .043 & 7.128 & .000 & .345 & 1.593 \\
(Constant) & .706 & .180 & 3.930 & .000 & - & - \\
\hline
\end{tabular}

a. Predictors: Entertainment, Interaction, Trendiness, Customization, eWOM, (Constant).

b. Dep. Variable: Purchase Intention, $R^{2}=0.419$, Adjusted $R^{2}=0.412, F(5,394)=56.907, p<.001$. 
Sixthly, a bivariate regression was conducted to examine how customer inspiration predicts purchase intention. A scatterplot showed that the relationship between customer inspiration and purchase intention was positive and linear and did not reveal any bivariate outliers. The correlation between purchase intention and customer inspiration was statistically significant, $\mathrm{r}(398)=0.629, \mathrm{p}<0.001$. The regression equation for predicting purchase intention from customer inspiration was $\hat{y}=1.002+0.750 X$ (Customer Inspiration). The $\mathrm{R}^{2}$ for this equation was 0.394 ; that is, $39.4 \%$ of the purchase intention variance was predictable from customer inspiration. Therefore, according to Henseler (2010), this is a moderate relationship. The bootstrapped $95 \%$ confidence interval for the slope to predicate purchase intention from customer inspiration range from 0.841 to 0.659 with a $B=.750$; thus, for each one-unit increase of customer inspiration, purchase intention increases by 0.659 to 0.841 points.

Table 10. Linear Regression Analysis between Customer Inspiration and Customer Purchase Intention ( $n=400)$

\begin{tabular}{cccccc}
\hline Variables & $\mathrm{B}$ & $\mathrm{SE}$ & $\mathrm{t}$ & $\beta$ & $\mathrm{VIF}$ \\
\hline $\mathrm{CI}$ & .750 & .046 & 16.146 & .629 & 1.000 \\
(Constant) & 1.002 & .146 & 6.871 & - & - \\
\hline
\end{tabular}

a. Predictors: $\mathrm{CI}$ (Constant).

b. Dependent Variable: PI, $R^{2}=0.396$, Adjusted $R^{2}=0.394, F(1,398)=260.687, p<.001$.

Seventhly, the Path Analysis (PA) was used to verify the proposed hypotheses. In PA, the path coefficient ( $\beta$ ) connecting two constructs is assessed. Hair, Sarstedt, Ringle, \& Mena (2012) argued that for a definite impact in the model, $\beta$ value is required to be at least 0.1 . As indicated in Table 11, the path coefficient's evaluation illustrates that every projected hypothesis is supported. The model was significant as the values were equal to $(0.000)$, which is less than 0.05 , and it is considered sufficient for the significance of hypotheses.

Partial Eta Squared $(\eta 2)$ as the effect size indicator was $\eta 2=.081$, which indicates a strong effect. The power of interaction effect was .99 , which means that if the study were to be replication 100 times, we would correctly reject the null hypothesis on $99 \%$ of those replications. We used the original sample size $(n=400)$ for the bootstrapping process, and we resample it 2000 times using the resampling method.

Table 11. Hypotheses Testing

\begin{tabular}{lcccc}
\hline \multicolumn{1}{c}{ Research Hypotheses } & $\beta$ & $\mathrm{t}$ & Sig. & Result \\
\hline $\begin{array}{l}\text { H1: Social media marketing has a positive impact on } \\
\text { customer inspiration. }\end{array}$ & .717 & 20.538 & .000 & Supported \\
$\begin{array}{l}\mathrm{H}_{2} \text { : Social media marketing has a positive impact on } \\
\text { customer purchase intention. }\end{array}$ & .636 & 16.462 & .000 & Supported \\
$\begin{array}{l}\mathrm{H}_{3} \text { : Customer inspiration has a positive impact on } \\
\text { customer purchase intention. }\end{array}$ & .629 & 16.146 & .000 & Supported \\
\hline
\end{tabular}

\section{Discussion and Conclusions}

The study results support the proposed hypothesis regarding the positive impact of social media marketing on purchase intention $\left(\mathrm{H}_{2}\right)$, which is coherent with the existing literature. Tuten \& Solomon (2017) illustrated that the shaping of customer decision-making is a major goal of using social media to promote and communicate. According to Balakrishnan et al. (2014), online marketing communications, especially electronic word of mouth, online communities, and online advertising, effectively foster brand loyalty and purchase intention via corporate websites and social media platforms. Moreover, Schivinski \& Dabrowski (2016) showed that users' social media communication has a positive influence on brand equity and brand attitude, while social media communication created by corporations only affected brand attitudes. Both brand equity 
and brand attitudes have a positive impact on purchase intention. Worldwide organizations use social media platforms to invest a great deal in promoting their products. Therefore, the effectiveness of such promotions and whether they might draw more customers are also concerned(Alalwan, 2018). According to Shareef, Mukerji, Dwivedi, Rana, \& Islam (2019), social media advertising should also be designed and organized so that all the important factors focusing on customers are taken into consideration. Accordingly, based on the study's multiple regression results, $41.9 \%$ of the variance in purchase intention was predictable from social media marketing factors (Entertainment, Interaction, Trendiness, Customization, and eWOM). As depicted in Table 9, apart from the entertainment and trendiness, all factors were found to impact purchase intention significantly.

The formulated hypothesis about the positive impact of social media marketing on customer inspiration $\left(\mathrm{H}_{1}\right)$; is also supported by the findings of this study, which has not been empirically investigated previously. Böttger's (2015) study pointed out that customer inspiring raises spending according to the motivational aspect of motivation, by increasing the desire to purchase a product. In a Malaysian context, Ghouri et al. (2019) proposed that consumer inspiration mediates market-orientated sub-construction with customer loyalty. Digital media offers collaborative touch-points for customers to be reached. According to Nathues (2017), more work is required to demonstrate the effectiveness of inspiration in marketing, across industries, and context. For example, research should be performed using various marketing stimuli that make conclusions about inspiration's effectiveness. In addition to motivating stimuli, the researcher suggested; it is important to examine the media used to express the stimuli, as in social media. Accordingly, based on the study's statistical results, $52.0 \%$ of the variance in customer inspiration was from social media marketing factors. As shown in Table 7, aside from trendiness and customization, all factors were found to impact customer inspiration significantly.

Moreover, the suggested hypothesis regarding the positive impact of customer inspiration on purchase intention $\left(\mathrm{H}_{3}\right)$ is as well supported by the findings that have not been empirically examined previously. As seen in Table 10, based on bivariate regression results, $39.4 \%$ of the purchase intention variance was predictable from customer inspiration. Thus, by revealing a significant positive relationship between social media marketing, customer inspiration, and customer purchase intention, this study filled the customer inspiration literature gap.

With a $+8.6 \%$ annual digital growth, social media users represent approximately $9 \%$ of the Afghan population (Internews, 2017). Thus, Afghanistan has about 3.42 million active social media users. As stated in Table 3, fifty-seven percent of social media users spend $4-6$ hours on social media platforms, and $40 \%$ of them visit at least five times per month their telecommunication company social media accounts. Given these numbers, Afghanistan provides a credible platform to research on social media marketing.

The results are useful in developing an effective social media marketing strategy for businesses and digital marketers to optimize the impacts of consumer inspiration and customer purchase intention through social media marketing. The digital transformation expanded touch-points for customers, and emerging technology creates more opportunities for the customer to inspire during the entire decision-making process and provide inspiration as a new marketing function (Böttger, 2015). Accordingly, this study showed that social media marketing would increase customer inspiration and customer purchase intention. Rudolph, Nagengast, and Weber (2014) demonstrated that brands could increase awareness, engagement, and, ultimately, sales through inspiring customers with abstract thinking. According to Lovemarks Campus (2011), inspired customers are brand supporters, community members, and brand owners.

This study is based on cross-sectional data using convenience sampling in Afghanistan's telecom industry. Therefore, to better understand the impacts of social media marketing on customer inspiration and customer purchase intention, and to better generalize the results; a longitudinal study and empirical research on different industries, context, and nationalities are recommended using different sampling methods. The impact of social media as conveying stimuli is explored in this study. Hence, future studies should also research some other media types and technologies used to convey the stimuli. 


\section{References}

Alalwan, A. A. (2018). Investigating the impact of social media advertising features on customer purchase intention. International Journal of Information Management. https://doi.org/10.1016/j.jijinfomgt.2018.06.001

Appel, G., Grewal, L., Hadi, R., \& Stephen, A. T. (2019). The future of social media in marketing. Journal of the Academy of Marketing Science. https://doi.org/10.1007/s11747-019-00695-1

Balakrishnan, B. K. P. D., Dahnil, M. I., \& Yi, W. J. (2014). The Impact of Social Media Marketing Medium toward Purchase Intention and Brand Loyalty among Generation Y. Procedia - Social and Behavioral Sciences, 148, 177-185. https://doi.org/10.1016/j.sbspro.2014.07.032

Bolton, R. N., \& Drew, J. H. (1991). A longitudinal analysis of the impact of service changes on customer attitudes", Journal of Marketing, 55 (1): 1 9., 1991b. A multistage model of customers' assessments of service quality and value", Journal of Customer Research, 17(4), 375-384.

Böttger, T., Rudolph, T., Evanschitzky, H., \& Pfrang, T. (2017). Customer inspiration: Conceptualization, scale development, and validation. Journal of Marketing, 81(6), 116-131. https://doi.org/10.1509/jm.15.0007

Böttger, T. (2015). Inspiration in Marketing: Foundations, Process, and Application, Unpublished Doctoral Dissertation. University of St. Gallen, Germany.

Buffer. (2019). State of Social 2019 I Buffer, Available at: https://buffer.com/state-of-social-2019\# (Accessed December 19, 2019)

Ceyhan, A. (2019). The Impact of Perception Related Social Media Marketing Applications on Consumers' Brand Loyalty and Purchase Intention. EMAJ: Emerging Markets Journal, 9(1), 88-100.

Çinkay, B. (2017). The effect of celebrity endorsement on consumer perception and purchase intention in social media marketing, Unpublished Doctoral Dissertation. Kahramanmaraş Sütçü İmam University, Institute of social science, Kahramanmaraş.

Dummies, C. (2017). The different types of social media marketing. Retrieved May 28, 2020, from https://www.dummies.com/business/start-a-business/small-business-marketing/the-different-typesof-social-media-marketing/

eMarketer. (2018). Social Network Users and Penetration in Worldwide Forecasts, Estimates and Historical Data, Available at: https://www.emarketer.com/forecasts/5aa6c67d60a15705f86fb232/5a32f18fe0cb1d0dd489d2c2 (Accessed May 28, 2020)

Felix, R., Rauschnabel, P. A., \& Hinsch, C. (2017). Elements of strategic social media marketing: A holistic framework. Journal of Business Research, 70, 118-126. https://doi.org/10.1016/j.jbusres.2016.05.001

Gautam, V., \& Sharma, V. (2017). The mediating role of customer relationship on the social media marketing and purchase intention relationship with special reference to luxury fashion brands. Journal of Promotion Management, 23(6), 872-888.

Ghouri, A. M., Kin, T. M., Yunus, N. K. bin Y., \& Akhtar, P. (2019). The dataset for validation of customer inspiration construct in Malaysian context. Data in Brief, 25, 104131. https://doi.org/10.1016/j.dib.2019.104131

Gürbüz, S., \& Şahin, F. (2018). Sosyal bilimlerde araştırma yöntemleri (5. Baskı). Ankara: Seçkin Yayıncılık.

Hair, J. F., Sarstedt, M., Ringle, C. M., \& Mena, J. A. (2012). An assessment of the use of partial least squares structural equation modeling in marketing research. Journal of the academy of marketing science, 40(3), 414-433.

Henseler, J. (2010). On the convergence of the partial least squares path modeling algorithm. Computational Statistics, 25(1), 107-120. https://doi.org/10.1007/s00180-009-0164-x 
Internews. (2017). Social Media in Afghanistan. Media, Available at: https://internews.org/news/social-mediaafghanistan-users-and-engagement (Accessed May 28, 2020)

Karayalçin, C. (2019). The effect of perceived social media marketing efforts on brand value and purchase intention: a research on the social media affiliation and usage frequency of consumers, Unpublished Doctoral Dissertation. Akdeniz University, Institute of social science, Antalya.

Khan, M., \& Ghouri, A. M. (2018). Enhancing Customer Satisfaction and Loyalty through Customer-Defined Market Orientation and Customer Inspiration: A Critical Literature Review. International Business Education Journal, 11(1), 25-39.

Kim, A. J., \& Ko, E. (2012). Do social media marketing activities enhance customer equity? An empirical study of luxury fashion brand. Journal of Business Research, 65(10), 1480-1486. https://doi.org/10.1016/j.jbusres.2011.10.014

Laksamana, P. (2018). Impact of social media marketing on purchase intention and brand loyalty: Evidence from Indonesia's banking industry. International Review of Management and Marketing, 8(1), 13-18.

Lovemarks Campus (2011). The value of the inspirational consumer. Available at: http://www.lovemarkscampus.com/the- value-of-the-inspirational-consumer/ (Accessed November $3,2016)$

Lu, L., Chang, W., \& Chang, H. (2014). Consumer attitudes toward blogger's sponsored recommendations and purchase intention: The effect of sponsorship type, product type, and brand awareness. Computers in Human Behavior, 34, 258-266. doi:10.1016/j.chb.2014.02.007

Lua, A. (2019). 21 Top Social Media Sites to Consider for Your Brand, Available at: https: //buffer.com/library/social-media-sites (Accessed April 26, 2020)

Nathues, E. (2017). From interruption to interaction: inspiration as a new marketing discipline. Marketing of the 21st century. University of Twente, the Netherlands.

Pfrang, T., Rudolph, T., \& Böttger, T. (2014). Inspire to Delight: the Effects of Customer Inspiration on Consumers' Purchase Decisions. (June), 227.

Rudolph, T., Nagengast, L., \& Weber, M. (2014). Profilierung und Kundeninspiration: Wachstum in umkämpften Märkten 1, 239. Forschungszentrum für Handelsmanagement.

Schivinski, B., \& Dabrowski, D. (2016). The effect of social media communication on consumer perceptions of brands. Journal of Marketing Communications. https://doi.org/10.1080/13527266.2013.871323

Sekaran, U., \& Bougie, R. (2003). Research Methods For Business, A Skill Building Approach, John Willey \& Sons. Inc. New York.

Shareef, M. A., Mukerji, B., Dwivedi, Y. K., Rana, N. P., \& Islam, R. (2019). Social media marketing: Comparative effect of advertisement sources. Journal of Retailing and Consumer Services, 46, 58-69.

Thrash, T. M., \& Elliot, A. J. (2004). Inspiration: core characteristics, component processes, antecedents, and function. Journal of personality and social psychology, 87(6), 957.

Tuten, T. L., \& Solomon, M. R. (2017). Social media marketing. New Jersey: Sage. Usher, K., Woods, C., Casella, E., Glass, N., Wilson, R., Mayner, L., et al. (2014).

Ural, T., \& Yuksel, D. (2015). The Mediating Roles of Perceived Customer Equity Drivers Between Social Media Marketing Activities and Purchase Intention. International Journal of Economics, Commerce and Management, 3(10), 1-18. https://doi.org/2348 0386 